\title{
MIRLET7B wt Allele
}

National Cancer Institute

\section{Source}

National Cancer Institute. MIRLET7B wt Allele. NCI Thesaurus. Code C81853.

The human MIRLET 7B wild-type allele is located in the vicinity of $22 q 13.31$ and is 82 bases in length. This allele, which encodes MIRLET7B RNA, plays a role in development of lung cancer and melanoma. 